\title{
Dynamic regulation of pituitary mRNAs for bone morphogenetic protein (BMP) 4, BMP receptors, and activin/inhibin subunits in the ewe during the estrous cycle and in cultured pituitary cells
}

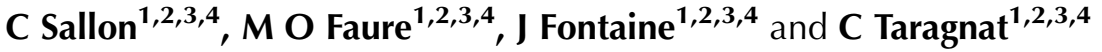 \\ ${ }^{1}$ Centre INRA de Tours, UMR85 Physiologie de la Reproduction et des Comportements, F-37380 Nouzilly, France \\ ${ }^{2}$ CNRS, UMR 6175, F-37380 Nouzilly, France \\ ${ }^{3}$ Université de Tours, F-37041 Tours, France \\ ${ }^{4}$ Haras Nationaux, F-37380 Nouzilly, France \\ (Correspondence should be addressed to C Taragnat at Centre INRA de Tours; Email: catherine.taragnat@tours.inra.fr)
}

\begin{abstract}
Recently, bone morphogenetic protein (BMP) 4 has been shown to inhibit FSH secretion in ewe. The detection of BMP4 mRNA and BMP receptors in the pituitary suggests that BMP4 can exert paracrine actions on FSH production. This work aimed at determining whether BMP4 and/or BMP receptor mRNA as well as activin/inhibin subunit mRNA fluctuates during the estrous cycle when FSH $\beta$ mRNA and FSH release changed. The estrous cycles of ewes were synchronized with progestagen sponges. Ewes were killed in late follicular stage $(n=5)$, before the secondary FSH surge $(n=4)$, and in luteal phase $(n=4)$. Using quantitative reverse transcription-PCR, we showed that the levels of mRNA for BMP4, BMP receptor, the inhibitor of differentiation 2 (Id2), a target gene of BMP4, and noggin did not change significantly across the estrous cycle.

In contrast, the level of activin $\beta \mathrm{B}$ mRNA and the percentage of immunoreactive cells for activin $\beta \mathrm{B}$-subunit were higher before the secondary surge of FSH compared to other groups. In ewe pituitary cell cultures, activin, GnRH, or estradiol$17 \beta\left(E_{2}\right)$ did not significantly affect the levels of BMP4, BMP receptor, and Id 2 mRNA. $E_{2}$, but not $\mathrm{GnRH}$, increased the level of activin $\beta \mathrm{B}$ mRNA. Moreover, the in vitro FSH release was not modified by noggin, a BMP antagonist. In contrast, SB431542, an inhibitor of activin pathway, inhibited FSH release. Collectively, our data showed that pituitary BMP4 would not play a crucial role in the regulation of FSH production during the estrous cycle, whereas local activin $\mathrm{B}$ would be a major stimulus of FSH synthesis necessary for the secondary FSH surge.

Journal of Endocrinology (2010) 207, 55-65
\end{abstract}

\section{Introduction}

In mammals, the gonadotropins FSH and LH are essential components for reproduction (Morel et al. 1981). Synthesis and release of LH and FSH by gonadotrope cells are regulated by a complex interplay of hypothalamic, gonadal, and pituitary factors. The hypothalamic $\mathrm{GnRH}$ is the major regulator of $\mathrm{LH}$ and FSH secretion. While the $\mathrm{LH}$ secretion is mainly dependent of GnRH and gonadal steroids, additional factors are involved in regulation of $\mathrm{FSH}$ production. Particularly, activins and inhibins, members of the transforming growth factor- $\beta$ (TGF- $\beta$ ) superfamily, are able to stimulate (Ling et al. 1986) and inhibit (Carroll et al. 1989) FSH synthesis and release respectively. Activin is a dimer of two highly related $\beta$-subunits ( $\beta A$ and/or $\beta B$ ), resulting in three possible molecular species: activin $A(\beta A \beta A)$, activin $B$ $(\beta B \beta B)$, and activin $A B(\beta A \beta B)$. Inhibin is a heterodimer composed of one $\alpha$-subunit and one $\beta$-subunit ( $\beta A$ or $\beta B$ ). The activin and inhibin subunits are produced in both ovary and pituitary gland in different species, including rat
(Kogawa et al. 1991, Wilson \& Handa 1998), human (Uccella et al. 2000), and sheep (Baratta et al. 2001). Activin is thought to play an autocrine/paracrine action on FSH secretion (Padmanabhan \& McNeilly 2001). Indeed, monoclonal antibodies to activin B inhibit FSH release from plated pituitary cells as well as from hypophysectomized, pituitarygrafted rats (Corrigan et al. 1991, DePaolo et al. 1992). Inhibin is produced by gonads and exerts an endocrine action on FSH secretion (de Kretser \& Robertson 1989), mainly through antagonism of activin action (Lewis et al. 2000, Bilezikjian et al. 2004).

Recently, other members of the TGF- $\beta$ superfamily, the bone morphogenetic proteins (BMPs), were shown to regulate FSH production in vitro. In rat pituitary cells and murine L $\beta$ T2 gonadotrope cell lines, BMP6 and BMP7 at high concentrations or BMP2 and BMP15 at lower concentrations stimulate basal FSH secretion and FSH $\beta$ promoter activity (Huang et al. 2001, Otsuka \& Shimasaki 2002, Lee et al. 2007). Moreover, BMP4 increased the release of FSH in response to activin and activin $+\mathrm{GnRH}$ 
(Nicol et al. 2008). In contrast, in ovine pituitary cells, BMP4 inhibits the FSH and is able to antagonize the effects of activin (Faure et al. 2005, Young et al. 2008). To initiate their intracellular signaling cascade, BMPs bind to two types of serine-threonine kinase receptors, BMP receptor type I (BMPR1A or BMPR2B also known as ALK3 and ALK6 respectively) and BMP receptor type II (BMPR2; Kawabata et al. 1998, Miyazono et al. 2001, Allendorph et al. 2006). Some ligands such as BMP2 first bind BMPR1A (ALK3). Upon ligand binding, the constitutively phosphorylated type II receptor transphosphorylates the type I receptor. Consequently, activated type I receptors phosphorylate intracellular mediators Smad1, Smad5, or Smad8, which then interact with Smad4. This complex translocates to the nucleus, where it regulates gene expression (Zwijsen et al. 2003).

In the ewe pituitary, the mRNA encoding BMP4 is present, as well as BMPR1A (ALK3), BMPR1B (ALK6), and BMPR2 (Faure et al. 2005). Furthermore, both BMPR1A (ALK3) and BMPR2 are immunodetected on the gonadotrope cells (Faure et al. 2005), suggesting that BMP4 may exert paracrine/autocrine actions on FSH production and participate with activin in FSH regulation. However, the physiological relevance of pituitary BMP4 in the control of the FSH synthesis and release has not yet been established.

If $\mathrm{BMP} 4$ is a regulator of $\mathrm{FSH}$, the expression of the ligand, receptors or antagonists may exhibit changes at mRNA or protein level leading to corresponding changes in $\mathrm{FSH}$ secretion. In the ewe, it is true for activin receptors since the mRNA for ActR1A (ALK2), ActR1B (ALK4), and ActR2B fluctuates across the estrous cycle (Fafioffe et al. 2004). Whether activin ligands are changing in the pituitary is not known.

In order to gain an insight into potential intrapituitary role of BMP4 in the regulation of FSH synthesis and release, the present study was designed to determine whether changes in the patterns of FSH $\beta$ gene expression and FSH secretion observed in vitro and in vivo during the ewe estrous cycle were associated with variations in the expression of the BMP4 system, i.e. ligand, BMP receptors, noggin antagonist, and $I d 2$, a target gene for BMP4. In the absence of available antibodies and protein immunoassays for ovine BMPs, we focused on mRNA levels. To compare the BMP system to those of activin, the pattern of activin subunit expression in the pituitary during the estrous cycle and in vitro was investigated.

\section{Materials and Methods}

\section{Reagents}

Cell culture reagents used were DMEM and F12 (nutrient mixture F-12 Ham) from Sigma. FCS and BSA were purchased from Sigma. Collagenase A and DNase I were obtained from Roche Diagnostics Ltd. Human recombinant activin-A and BMP4 were obtained from R\&D Systems
(Lille, France). Estradiol-17 $\beta \quad\left(\mathrm{E}_{2}\right)$ and $\mathrm{SB} 431542$ were obtained from Sigma. GnRH (Relefact LH-RH) was obtained from Aventis (Frankfurt, Germany). Human noggin was kindly provided by Regeneron (Tarrytown, NY, USA).

\section{Pituitary collection during the estrous cycle}

The estrous cycles of 15 Ile de France ewes were synchronized by insertion of vaginal sponges impregnated with synthetic progestagen during the breeding season. Sponges remained in place for 12 days. Ewes were killed at different stages of the estrous cycle: 36 h (group A), 48 h (group B), 66 h (group C), or $240 \mathrm{~h}$ (group D) after sponge removal. Prior to killing, blood samples were collected from the jugular vein at $2 \mathrm{~h}$ intervals between 32 and $36 \mathrm{~h}$ for group A, 32 and $48 \mathrm{~h}$ for group B, and 32 and $66 \mathrm{~h}$ for group C. For group D, a single blood sample was collected just prior to killing. Plasma was recovered from these samples and assayed for $\mathrm{LH}, \mathrm{FSH}$, and $\mathrm{E}_{2}$. Anterior pituitaries were collected immediately after slaughtering and hemisected midsagitally. One half of pituitary was stored at $-80{ }^{\circ} \mathrm{C}$ until RNA extraction, and the other half was fixed for $72 \mathrm{~h}$ in Bouin-Hollande fixative containing $\mathrm{HgCl}_{2}$ for immunohistochemistry as previously described (Taragnat et al. 1998). All procedures were approved by the Agricultural and Scientific Research agencies, and conducted in accordance with the guidelines for Care and Use of Agricultural Animals in Agricultural Research and Teaching.

\section{Pituitary collection for cell culture}

Pituitaries from Ile de France ewes were collected during the non-breeding season and dissociated for cell cultures as previously described (Faure et al. 2005). Pituitaries were finely sliced and placed in F12 supplemented with collagenase A $(0.4 \mathrm{mg} / \mathrm{ml})$ and DNase I $(0.025 \mathrm{mg} / \mathrm{ml})$, and then incubated for $1 \mathrm{~h} 30 \mathrm{~min}$ in a shaking water bath at $37^{\circ} \mathrm{C}$ followed by manual dispersion through different sizes of syringe. Cells were then centrifuged at $100 \mathrm{~g}$ for $5 \mathrm{~min}$, and the pellet was resuspended in culture medium (DMEM containing 5\% FCS). Cells were plated in 6 -well plates at $3 \times 10^{6}$ cells $/$ well in $2 \mathrm{ml}$ of culture medium (DMEM with 5\% FCS), and allowed to attach for 2 days in a humidified atmosphere with $5 \% \mathrm{CO}_{2}$ at $37^{\circ} \mathrm{C}$. Media were replaced with serum-free DMEM containing $0 \cdot 1 \%$ BSA. One hour later, media were changed and replaced by DMEM- $0 \cdot 1 \%$ BSA alone (control) or supplemented with test substances at different concentrations (see Results). The choice of concentrations was based on our previous studies determining $10^{-8}, 10^{-9}$, and $10^{-9} \mathrm{M}$ as optimal doses for $\mathrm{GnRH}$, activin, and $\mathrm{E}_{2}$ respectively to regulate $\mathrm{FSH}$ secretion in vitro. Media were collected for measurement of secreted FSH by ELISA. Total RNA was extracted from cells for measurement of studied mRNA levels by quantitative reverse transcription (RT)-PCR. 
Gonadotropin measurements by ELISA

The concentrations of ovine gonadotropins in blood plasma or in culture cell media were determined using doubleantibody ELISA for all experiments, as previously described by Faure et al. (2005) with a sensitivity of $0 \cdot 1 \mathrm{ng} / \mathrm{ml}$ for ovine $\mathrm{LH}(\mathrm{oLH})$ and $0.4 \mathrm{ng} / \mathrm{ml}$ for ovine FSH (oFSH). For LH, the intra- and inter-assay coefficients of variation (CV) of the control averaged 4 and 10\% respectively. The cross reaction with oFSH was $0 \cdot 01 \%$. For FSH, the intra- and inter-assay $\mathrm{CV}$ of the control were $2 \cdot 6$ and $2 \cdot 1 \%$ respectively. The cross reaction with oLH was $0 \cdot 07 \%$.

\section{$E_{2}$ measurements by $R I A$}

For steroid assays, $600 \mu \mathrm{l}$ plasma was extracted with ethyl acetate-cyclohexane as described (Monniaux et al. 2008), and the dried extracts containing steroids were measured by RIA. $E_{2}$ was assayed with the $E_{2}$ RIA kit following the manufacturer's specifications (Diasorin SA, Antony, France). The limit of detection of the assay was $0.08 \mathrm{pg}$ per tube. The intra- and inter-assay CV of the control were 3.8 and $8 \cdot 7 \%$ respectively.

Quantitative RT-PCR from tissue and from pituitary cell cultures

Levels of mRNA for BMP4, BMP receptors, Id2, inhibin $\alpha$-subunit, activin $\beta A$ - and activin $\beta B$-subunits were measured using SYBR Green RT-PCR. Total RNA from 6-well plates (plated at $3 \times 10^{6}$ cells/well) and from tissue was extracted using TRI Reagent (Sigma) and kit NucleoSpin RNA L (Macherey-Nagel, Hoerdt, France) respectively according to the manufacturer's instructions. Remaining DNA was removed by RNase-free DNase treatment. cDNA was synthesized from $1 \mu \mathrm{g}$ RNA in a volume of $20 \mu \mathrm{l}$ containing $150 \mathrm{ng}$ oligodT (Promega), $1 \mathrm{mM}$ dNTPs, $20 \mathrm{U}$ of RNasin, $1 \times$ RT PCR buffer, and $12 \mathrm{U}$ M-MLV reverse transcriptase (Promega). For the negative control, the reverse transcriptase was omitted. The RNA denaturation was performed at $70^{\circ} \mathrm{C}$ for $10 \mathrm{~min}$, and the RT was performed at $37^{\circ} \mathrm{C}$ for $1 \mathrm{~h}$.

For PCR, each reaction consists of a final reaction volume of $20 \mu \mathrm{l}$ containing iQ SYBR Green Supermix (Bio-Rad) $(1 \times), 3 \mu \mathrm{M}$ of each gene-specific primer, and cDNA. Primers were designed using Beacon Designer Software (Premier Biosoft International, Palo Alto, CA, USA), and sequences are described in Table 1 . The equivalent of 5-50 ng of starting RNA was used in each reaction. Each sample was assayed in duplicate. Quantitative real-time PCR was run on an iCycler from Bio-Rad. The amplification program consisted of $95^{\circ} \mathrm{C}$ for $30 \mathrm{~s}$ followed by up to 40 cycles of $95^{\circ} \mathrm{C}$ for $30 \mathrm{~s}, 58-61{ }^{\circ} \mathrm{C}$ for $30 \mathrm{~s}$, and $72{ }^{\circ} \mathrm{C}$ for $20 \mathrm{~s}$. Annealing temperatures are given in Table 1.

Prior to analysis, amplification efficiency was determined for each gene by generating a standard curve using serial dilutions of the cDNA, obtained after reverse transcriptase of the RNA, in abscissa and the corresponding cycle

Table 1 Oligonucleotide primer sequences used for real-time PCR

\section{GenBank}

AY158223

L19

$\mathrm{FSH} \beta$

NM_001009798

BMP4

DQ192013

BMPR1A

NM_001076800

BMPR1B

AF312016

BMPR2

XM_617592

Id2

NM_001034231

Noggin

DQ152984

Activin $\beta B$ (tissue)

FJ167874

Activin $\beta B$ (cell)

FJ167874

Activin $\beta A$

L19218

Inhibin $\alpha$

L28815
Sequence

Annealing temperature $\left({ }^{\circ} \mathrm{C}\right)$

Product size $(b p)$

5'-AATCGCCAATGCCAACTC

3'-CCCTTTCGCTTACCTATACC

5'-GTAGCCTCAATGCCTAACACTC

3'-ATAGCCTCTAACATCCTCTCTCAG

5'-GCCGACCATCAACTCAAC

3'-AGAACCACCTTGTCATACTCATCC

5'-TGTCGGACCAACTTATGTAACCAG

3'-TGAGCAAAGCCAGCCATCG

5'-GGTGGAGCAGTGACGAGTG

3'-TCTTGAGGCAGGATTGTGAGC

5'-AGGTGTTCTGGATCGTCTTGTG

3'-CATGGATTGCTGTTGTTGTTGTTG

5'-CGCGGTCAGCATGAAAGCC

3'-GGTTTTGCTCCGGGAGATGC

5'-TGCGGAGGAAGTTACAGATGTGG

3'-ACGGACTTGGACGGCTTGC

5'-GACAGCAGGCACCGCATC

3'-CGCAGTAGTTCCCGTAGTAGC

5'-GCGGAAGGTGCGGGTAAAGG

3'-TGGGTTCGGTGAGTGGGAAGG

5'-GTCACCATCCGTCTCTTTAAC

3'-CCCTTCAAGCCCACTTCCTC

5'-GACTGGACAGACAGGAGACC

3'-AGGACAACGCAGCAGGAG
60

156

58

123

59

146

61

100

59

77

60

87

61

91

60

172

59

148

61

122

60

86

59 
threshold $\left(C_{\mathrm{t}}\right)$ in ordinate. The slope of the log-linear phase reflects the amplification efficiency derived from the formula $E=\left(10^{- \text {slope }}-1\right) \times 100$. Amplification efficiency was included between 95 and 105\%, and was equivalent for test gene and the reference gene. Amplification was followed by melting curve analysis for each primer pair to verify the presence of one gene-specific peak and the absence of primer dimers. PCR products obtained with each set of primers were run on an agarose gel, and visualized using ethidium bromide and u.v. illumination to confirm amplification of a single product of the correct size. This was followed by sequencing of each amplicon to confirm the identity of amplified product, and the results were matched with the National Center for Bioinformatics Computing (NCBI-BLAST) database. Quantification of specific mRNA levels was performed by the $\Delta \Delta C_{t}$ method with the internal reference gene L19 (Bulletin \#2; PE Biosystems, Foster City, CA, USA). The intra- and inter-assay CV for tissue analyses were ranged between 1.3 and $6.6 \%$ and between 1.9 and $10.8 \%$ respectively. The intra- and inter-assay CV for cell analyses were $1 \cdot 5-6 \cdot 9$ and $3 \cdot 4-9 \cdot 7 \%$ respectively.

\section{Immunocytochemistry}

Affinity-purified polyclonal antisera raised in rabbits against synthetic fragments of porcine inhibin $\alpha$ (1-26)-Gly-Tyr, $\beta \mathrm{A}$ (81-113) $-\mathrm{NH}_{2}$, or $\beta \mathrm{B}(80-112)-\mathrm{NH}_{2}$ were kindly provided by $\mathrm{W}$ Vale and characterized previously (Vaughan et al. 1989). Pituitary sections $(7 \mu \mathrm{m})$ were incubated for $20 \mathrm{~min}$ in $0.3 \%$ hydrogen peroxide, rinsed with $0 \cdot 1 \mathrm{M}$ PBS $\left(\mathrm{NaHPO}_{4}, \mathrm{Na}_{2} \mathrm{PO}_{4}\right.$, and $\left.9 \mathrm{~g} \mathrm{NaCl} / \mathrm{l}\right)$, and exposed for 20 min to normal sheep serum (1:15 in PBS). Sections were then incubated for $2 \mathrm{~h}$ with $\alpha-, \beta \mathrm{A}-$, or $\beta \mathrm{B}$ antiserum diluted at $1 / 500,1 / 500$, or $1 / 1 / 2000$ respectively in PBS containing $0 \cdot 1 \%$ BSA. Washed sections were incubated for $1 \mathrm{~h}$ in biotinylated anti-rabbit gamma globulins, rinsed, and then exposed to avidin-biotin peroxidase complex (DAKO, Trappes, France) for $30 \mathrm{~min}$. The sections were then treated for $8 \mathrm{~min}$ with $0.04 \% 3,3^{\prime}$-diaminobenzidine tetrahydrochloride dihydrate (Sigma) and $0.03 \% \mathrm{H}_{2} \mathrm{O}_{2}$ in Tris- $\mathrm{HCl}(0 \cdot 05 \mathrm{M}, \mathrm{pH} 7 \cdot 8)$. Sections were coverslipped with Depex. All incubations were carried out in a humidified chamber at room temperature. Specificity of the staining was confirmed since immunostaining was abolished when non-immune rabbit serum was substituted for the primary antibody. Cells immunostained for $\alpha$ - or $\beta \mathrm{B}$-subunit and cells that were immunonegative were counted at $\times 40$ objective after counterstaining with hematoxylin. Data were calculated by counting $\sim 1000$ total cells from three randomly selected sections per animal in an immunohistochemistry assay. Two immunohistochemistry assays were performed per animal. The percentage of immunoreactive cells within the total cells was calculated as an average of the two immunohistochemistry assays for each animal.
Table 2 Changes in plasma concentrations of FSH, LH, and estradiol $\left(\mathrm{E}_{2}\right)$ during the estrous cycle. Mean plasma of $\mathrm{FSH}, \mathrm{LH}$, and $E_{2}$ concentrations for each group was calculated by averaging values from the last blood sample taken before killing each animal in each group. Values are the means \pm s.E.M.

\begin{tabular}{|c|c|c|c|}
\hline & $\begin{array}{l}\text { Late } \\
\text { follicular }\end{array}$ & $\begin{array}{l}\text { Before 2nd } \\
\text { FSH surge }\end{array}$ & Luteal \\
\hline Plasma $E_{2}(p g / m l)$ & $4 \cdot 7 \pm 0.99$ & $1 \cdot 02 \pm 0 \cdot 26$ & $0 \cdot 16 \pm 0 \cdot 16$ \\
\hline Plasma LH (ng/ml) & $0 \cdot 45 \pm 0 \cdot 10$ & $3 \cdot 02 \pm 1 \cdot 30$ & $0 \cdot 07 \pm 0.03$ \\
\hline Plasma FSH (ng/ml) & $0 \cdot 28 \pm 0 \cdot 12$ & $0.64 \pm 0 \cdot 20$ & $0.75 \pm 0.42$ \\
\hline
\end{tabular}

\section{Statistical analysis}

The levels of hormones and mRNAs during the estrous cycle and in cultured pituitary cells were compared using one-way ANOVA followed by the Newman-Keuls test. For estrous cycle experiment, two repetitions of RT-PCR using different

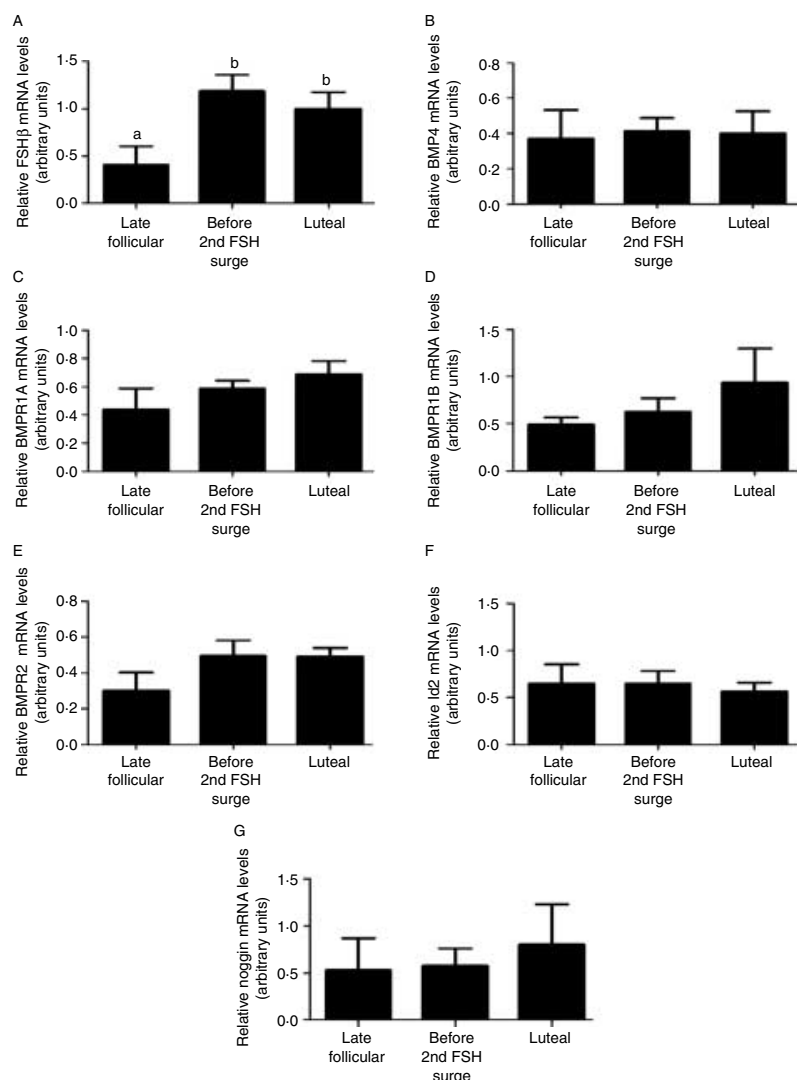

Figure 1 Changes in mRNA levels for FSH $\beta$ (A), BMP4 (B), BMPR1A $(\mathrm{C})$, BMPR1B (D), BMPR2 (E), Id2 (F), and noggin $(\mathrm{G})$ across the estrous cycle. Pituitaries were collected from ewes killed in late follicular phase $(n=5)$, before the secondary FSH surge $(n=4)$, and in luteal phase $(n=4)$. Total RNA was extracted from the pituitaries of each animal, and $1 \mu \mathrm{g}$ total RNA was analyzed by real-time RT-PCR and standardized by the level of L19 mRNA in each sample. Values are means \pm s.E.M. a versus $b, P<0 \cdot 05$. 


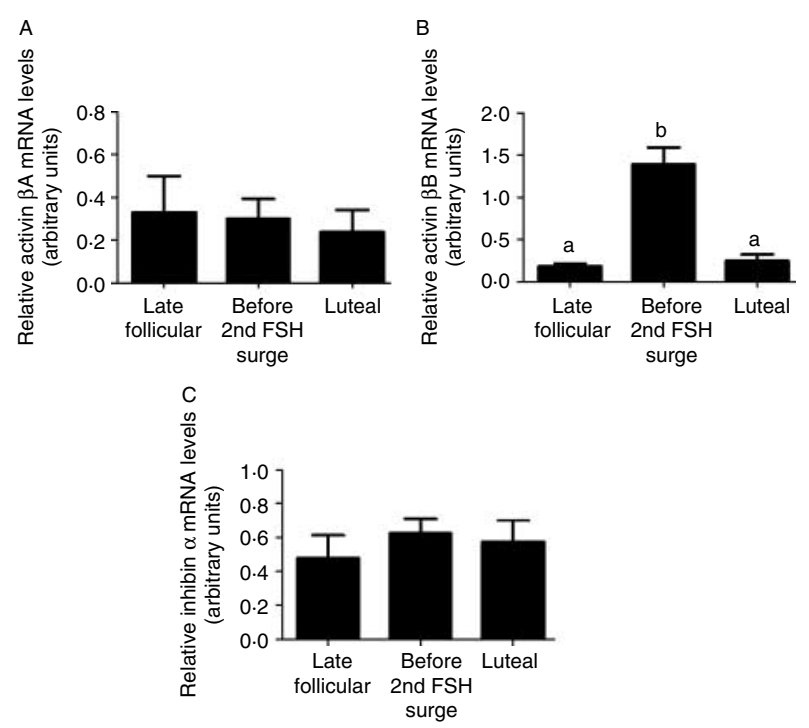

Figure 2 Changes in mRNA levels for activin $\beta A-(A)$, activin $\beta B-(B)$, and inhibin $\alpha-(C)$ subunits throughout the ewe estrous cycle. Pituitaries were collected from ewes killed in late follicular phase $(n=5)$, before the secondary FSH surge $(n=4)$, and in luteal phase $(n=4)$. Total RNA was extracted from the pituitaries of each animal, and $1 \mu \mathrm{g}$ total RNA was analyzed by real-time RT-PCR and standardized by the level of L19 mRNA in each sample. Values are the mean \pm s.E.M. a versus $b, P<0 \cdot 05$.

RNA samples from different pieces of pituitary from the same animal of each group were performed separately. The mean of these two repetitions represented the value of each animal. For culture experiments, at least three experiments were performed in duplicate when RNA was analyzed or in triplicate when FSH concentrations were measured. All results are expressed as means \pm S.E.M. Values of $P<0.05$ were considered statistically significant. The statistical analyses were performed using GraphPad Prism version 5.00 (GraphPad Software, San Diego, CA, USA).

\section{Results}

Plasma hormone concentrations during the estrous cycle

Plasma hormone concentrations and morphological analysis of ovaries allowed reclassification of animals into four groups. Thus, five ewes were killed before the preovulatory LH surge (group 1: late follicular, $n=5$ ), two ewes during the preovulatory LH surge (group 2: LH surge, $n=2$ ), four after ovulation (group 3: before the secondary FSH surge, $n=4$ ), and four during the luteal phase (group 4: luteal, $n=4$ ). Since there were only two animals in the LH surge group, we excluded this group from the following analyses. Plasma concentrations of $E_{2}$ in blood samples recovered at the time of killing gave further evidence for the correct timing (Table 2). $m R N A$ expression of $\mathrm{FSH} \beta$ during the estrous cycle

The mRNA levels for FSH $\beta$-subunit in the pituitaries were determined by real-time PCR (Fig. 1A). Mean FSH $\beta$ subunit mRNA levels varied during the estrous cycle. They increased before the secondary FSH surge compared to the late follicular phase $(P<0 \cdot 05)$.

$m R N A$ expression of BMP4, BMP receptors, Id2, and noggin during the estrous cycle

As shown in Fig. 1B-E, BMP4 and BMP receptor mRNA levels did not significantly change in the different stages of the estrous cycle. Similarly, the levels of mRNA for the inhibitor of differentiation 2 (Id2) reflecting the BMP4 bioactivity in vitro, since they are stimulated by BMP4 (see later), were similar in all studied stages of the estrous cycle (Fig. 1F). Further, the mRNA level for the BMP4 antagonist, noggin, did not significantly change over the estrous cycle (Fig. 1G).

$m R N A$ expression of activin $\beta A-$, activin $\beta B-$, and inhibin $\alpha$-subunits during the estrous cycle

The mRNA levels for activin $\beta \mathrm{A}$, activin $\beta \mathrm{B}$, and inhibin $\alpha$-subunits in the pituitaries were also evaluated by real-time PCR. The level of activin $\beta B$ mRNA increased before the secondary $\mathrm{FSH}$ surge compared with the other stages of
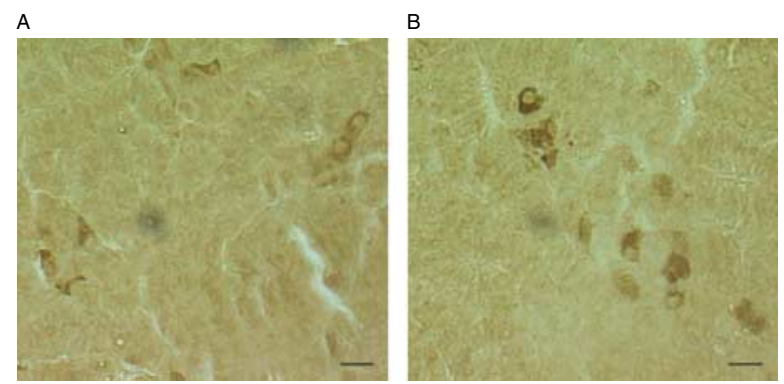

C
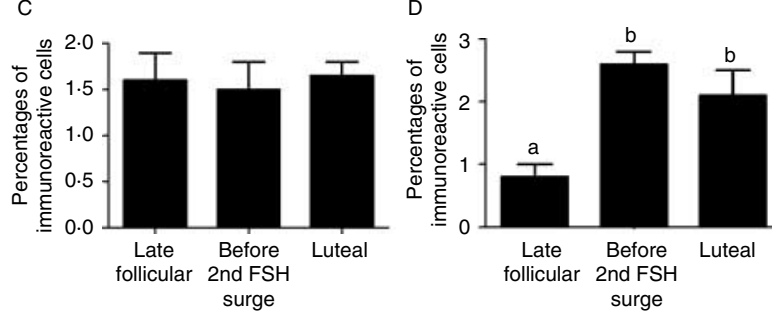

Figure 3 Immunostaining for inhibin $\alpha$-subunit (A) and activin $\beta B$-subunit (B) on section from ewe pituitary collected before the secondary surge of FSH. Scale bars represent $18 \mu \mathrm{m}$. Percentages of immunoreactive cells for inhibin $\alpha$-subunit (C) and activin $\beta B$-subunit (D) among the total pituitary cells during the estrous cycle. Pituitaries were collected from ewes killed in late follicular phase $(n=5)$, before the secondary FSH surge $(n=4)$, and in luteal phase $(n=4)$. Values are the mean \pm S.E.M. a versus $b, P<0 \cdot 05$. Full colour version of this figure available via http://dx.doi.org/10.1677/JOE-10-0035. 
the cycle (Fig. 2B). In contrast, the amounts of activin $\beta \mathrm{A}$ or inhibin $\alpha$ mRNA were similar in all studied stages of the estrous cycle (Fig. 2A and C).

\section{Percentage of pituitary cells expressing activin $\beta B$ - and inhibin} $\alpha$-subunits during the estrous cycle

The presence of $\alpha$ - and $\beta \mathrm{B}_{-}$, but not $\beta \mathrm{A}-$, subunits was confirmed by immunocytochemistry (Fig. 3A and B). The percentage of $\alpha$-subunit immunoreactive cells did not vary throughout the estrous cycle $(1 \cdot 6 \pm 0 \cdot 2 \%$ of total pituitary cells; Fig. 3C). In contrast, the percentage of $\beta \mathrm{B}$-subunit increased before the secondary FSH surge compared to the follicular phase $(2 \cdot 6 \pm 0 \cdot 2$ vs $0 \cdot 8 \pm 0 \cdot 1 \%$ of total pituitary cells, $P<0 \cdot 005$; Fig. 3D).

Effect of $G n R H$, activin, and $E_{2}$ on $m R N A$ expression of $B M P 4, B M P$ receptors, and Id 2 in cultured ovine pituitary cells

To determine whether major factors of FSH regulation, such as $\mathrm{GnRH}$, activin, or $\mathrm{E}_{2}$, were capable of modifying mRNA expression of BMP4 and/or BMP receptors, ovine pituitary cells were incubated with $10^{-8} \mathrm{M} \mathrm{GnRH}$ for $6 \mathrm{~h}$, or $10^{-9} \mathrm{M}$ activin or $10^{-9} \mathrm{M} \mathrm{E}_{2}$ for $48 \mathrm{~h}$. Figure $4 \mathrm{~A}$ shows that $6 \mathrm{~h}$ treatment with GnRH decreased the levels of FSH $\beta$ mRNA by $47 \%$ compared to basal conditions. Similar treatments with GnRH did not affect the mRNA levels for BMP4, BMPR1A (ALK3), BMPR1B (ALK6), BMPR2, and Id2 (Fig. 4B-F). When cells were treated for $48 \mathrm{~h}$ with activin or $\mathrm{E}_{2}$, the levels of FSH $\beta$ mRNA were increased by $29 \%$ $(P<0.05)$ or decreased by $63 \%(P<0.05)$ respectively compared to basal conditions (Fig. 5A). There was no significant change in the mRNA levels for BMP4, BMPR1A (ALK3), BMPR1B (ALK6), BMPR2, and Id2 (Fig. 5B-F). However, in the presence of $E_{2}$, the amount of mRNA for BMPR1B (ALK6) tended to increase compared to basal conditions $(P<0 \cdot 1$; Fig. $5 \mathrm{~B}$ and $\mathrm{D})$.

Effect of $G n R H$ and $E_{2}$ on $m R N A$ expression of activin $\beta B$ in cultured ovine pituitary cells

Treatment of pituitary cells with GnRH for $6 \mathrm{~h}$ did not significantly modify the amount of mRNA for activin $\beta B$ subunit (Fig. 4G). In contrast, treatment with $\mathrm{E}_{2}$ for $48 \mathrm{~h}$ increased the mRNA level $(P<0 \cdot 05$; Fig. $5 G)$.

\section{Noggin does not affect FSH release}

If BMP4 acts on FSH synthesis through a paracrine or autocrine mechanism, we can expect that blocking its action with an antagonist leads to an increase in FSH secretion. We first checked that noggin, a BMP binding protein, which antagonizes BMP signaling, was able to prevent the action of exogenous BMP4 on FSH release. As shown in Fig. 6A, noggin $(100 \mathrm{ng} / \mathrm{ml}$ for $24 \mathrm{~h}$ ) blocked the inhibitory action of BMP4 $(40 \mathrm{ng} / \mathrm{ml})$ on FSH release in ovine pituitary cells.
Similarly, it prevented the increase of Id2 mRNA level induced by BMP4 (Fig. 6B). However, noggin (from 10 to $100 \mathrm{ng} / \mathrm{ml}$ ) did not significantly modify FSH concentrations in the culture media (Fig. 6C). Moreover, noggin alone did not affect the level of Id2 mRNA (Fig. 6B).
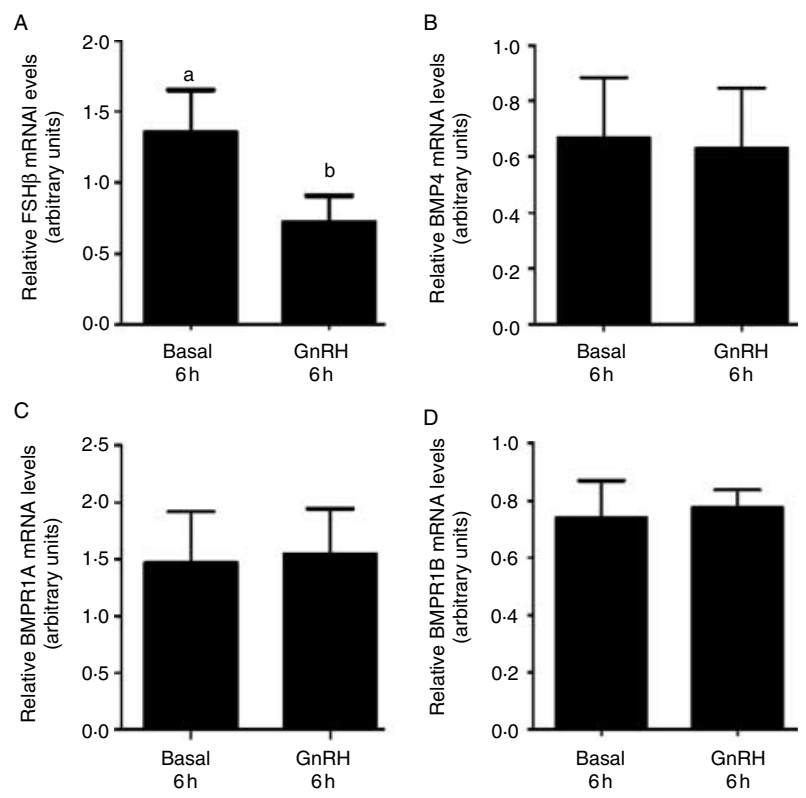

E

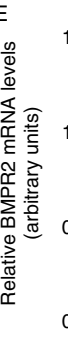

F
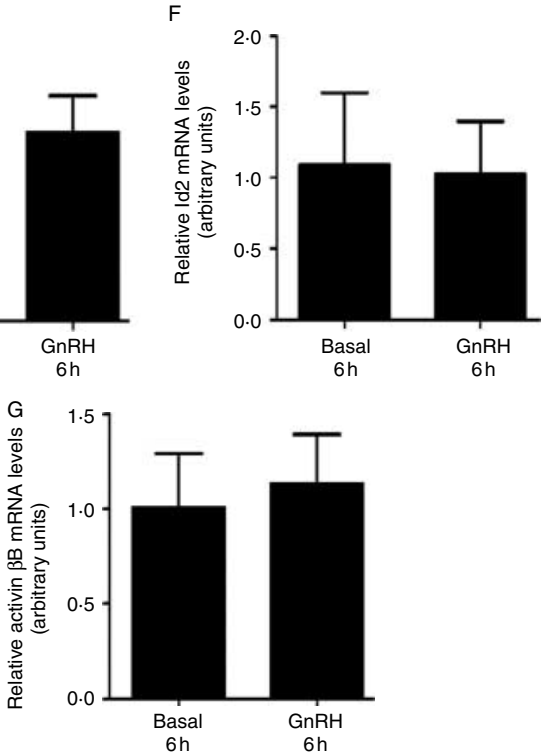

Figure 4 Effect of GnRH on the levels of mRNA for FSH $\beta(A)$, BMP4 (B), BMPR1A (C), BMPR1B (D), BMPR2 (E), Id2 (F), and activin $\beta B$-subunit $(G)$ from ewe pituitary cells. Cells were cultured in serum-free medium for $6 \mathrm{~h}$ with $\mathrm{GnRH}\left(10^{-8} \mathrm{M}\right)$ and harvested. Total RNA was extracted, and $1 \mu \mathrm{g}$ total RNA was analyzed by realtime RT-PCR and standardized by the level of L19 mRNA in each sample. Values are the mean \pm s.E.M. from at least three culture experiments with duplicate determinations. a versus $b, P<0 \cdot 05$ 

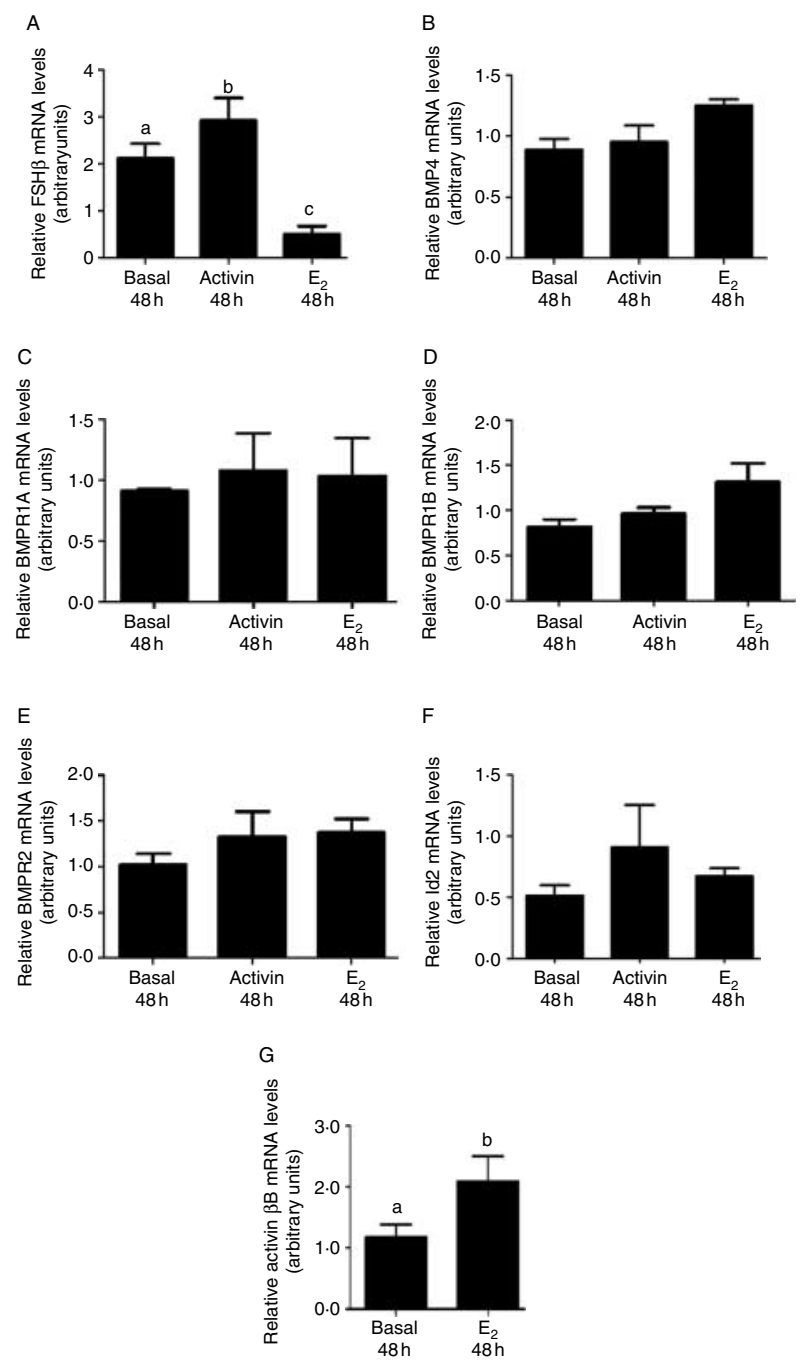

Figure 5 Effect of activin or $E_{2}$ on the levels of mRNA for $F S H \beta(A)$, BMP4 (B), BMPR1A (C), BMPR1B (D), BMPR2 (E), Id2 (F), and activin $\beta B$-subunit $(G)$ from ewe pituitary cells. Cells were cultured in serum-free medium for $48 \mathrm{~h}$ with activin $\left(10^{-9} \mathrm{M}\right)$ or $\mathrm{E}_{2}\left(10^{-9} \mathrm{M}\right)$ and harvested. Total RNA was extracted, and $1 \mu \mathrm{g}$ total RNA was analyzed by real-time RT-PCR and standardized by the level of L19 mRNA in each sample. Values are the mean \pm s.E.M. from at least three culture experiments with duplicate determinations. a versus $b, P<0 \cdot 05$.

\section{SB431542 affects FSH release}

The activin receptor-like kinase (ALK) 4/5/7 inhibitor, SB431542, is able to prevent the action of exogenous activin on FSH release (Fig. 7A). Moreover, treatment with SB431542 from 0 to $10 \mu \mathrm{M}$ for $24 \mathrm{~h}$ inhibited FSH secretion from pituitary cells in a dose-dependent manner (Fig. 7B). Preliminary analyses showed that the signaling capacity of BMP receptors assayed by the ability of BMP4 to induce Smad1 phosphorylation was not affected by SB431542 (data not shown).

\section{Discussion}

Several BMPs, in particular BMP4, are able to inhibit FSH $\beta$ mRNA expression and FSH release from ovine pituitary cells, whereas activin stimulates this secretion (Faure et al. 2005). The presence of BMP4 mRNA, as well as BMPR type IA (ALK3) and type II at the gonadotrope cell level in the adult pituitary, suggests that BMP4 can act within the pituitary and participate to control FSH synthesis and secretion in the ewe. A lot of studies raised the question of the mechanism of action of BMPs at the gonadotrope cell level, but no data are available concerning the possible changes of pituitary BMP system during the estrous cycle. To determine whether the variations in FSH $\beta$ mRNA and plasma FSH concentrations are associated with changes in the expression of BMP4 and BMP receptor mRNA as well as activin $\beta \mathrm{B}$ mRNA, three stages of the estrous cycle exhibiting variations of plasma $\mathrm{FSH}$ as previously shown (Leung et al. 1988, Fafioffe et al. 2004) were studied: late follicular phase, before the secondary FSH surge, and the luteal phase.

Our results showed that the levels of BMP4 mRNA in the pituitary did not significantly change between the studied stages of the estrous cycle when the level of FSH $\beta$ mRNA varied. In addition, the levels of BMPR1A (ALK3) and BMPR 2 mRNAs, as well as those of BMPR1B (ALK6), were similar over the estrous cycle. Other receptors beside BMPR1A (ALK3), BMPR1B (ALK6), and BMPR2 can be involved in signal transduction. For example, ALK2

A

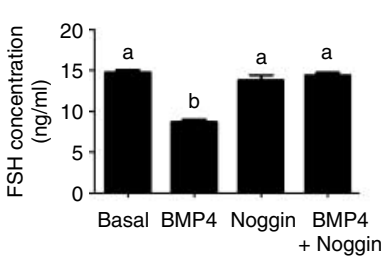

B
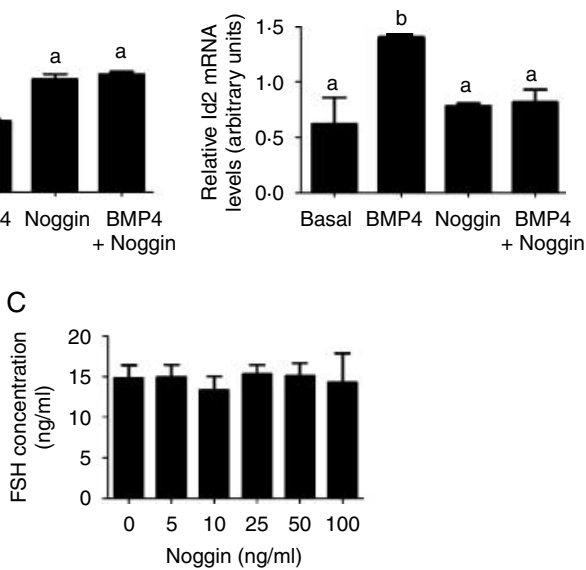

Figure 6 Effects of noggin (100 ng/ml) and BMP4 (40 ng/ml) on FSH release $(A)$ and $I d 2$ mRNA expression (B) in ewe pituitary cells.

Effect of increasing doses of noggin $(0-100 \mathrm{ng} / \mathrm{ml})$ on FSH release in ewe pituitary cells (C). Cells were cultured in serum-free medium for $24 \mathrm{~h}$ in the presence of indicated concentrations of noggin and/or BMP4. Media were collected, and the concentrations of FSH were determined by ELISA ( $A$ and $C$ ). Cells were harvested and total RNA was extracted, and $1 \mu \mathrm{g}$ total RNA was analyzed by real-time RT-PCR for Id2 mRNA and standardized by the level of L19 mRNA in each sample (B). Values are the mean \pm S.E.M. from three culture experiments with triplicate determinations for FSH concentrations measured and with duplicate determinations for RNA analyzed. a versus $b, P<0 \cdot 05$. 

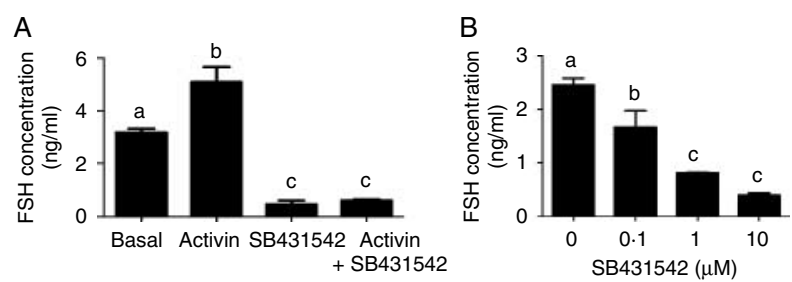

Figure 7 Effects of SB431542 $(10 \mu \mathrm{M})$ and activin $(40 \mathrm{ng} / \mathrm{ml})$ on FSH release in ewe pituitary cells (A). Effect of increasing doses of SB431542 $(0-10 \mu \mathrm{M})$ on FSH release in ewe pituitary cells (B). Cells were cultured in serum-free medium for $24 \mathrm{~h}$ in the presence of indicated concentrations of SB431542 and/or activin. Media were collected, and the concentrations of FSH were determined by ELISA. Values are the mean \pm S.E.M. from three culture experiments with triplicate determinations. a versus $\mathrm{b}$ versus $\mathrm{c}, P<0 \cdot 05$.

(also known as Acvr1) is able to induce BMP signaling (ten Dijke et al. 1994, Macias-Silva et al. 1998, Lee et al. 2007) and was previously shown to increase at the secondary FSH surge in ewe (Fafioffe et al. 2004). Nonetheless, BMP4 and BMP2 are known to bind to BMPR1A (ALK3) and BMPR1B (ALK6), whereas other BMPs bind more strongly to ALK2 (ten Dijke et al. 1994, Miyazono et al. 2010). In the murine gonadotrope cell line L $\beta$ T2, the endogenous signalpropagating type I receptor at least for BMP2, structurally close to BMP4, would be BMPR1A (Ho \& Bernard 2009). BMPs also show promiscuity in their binding to type II receptor. For example, in the absence of BMPR2, BMP2 and BMP4 can use ActR2A (Yu et al. 2005). However, BMPR2 is present on the gonadotrope cells. Moreover, the level of ActR2A mRNA is similar throughout the estrous cycle (Fafioffe et al. 2004). All together, these data led us to study preferentially BMPR2, BMPR1A, and BMPR1B. The lack of variations in the expression of BMP4 and BMP receptor mRNA does not necessarily mean that pituitary BMP4 activity does not change. For example, in the rat, neither activin $\beta B$ nor activin receptor mRNA expression changes at the time of the secondary FSH surge. Instead, the expression of follistatin, an activin binding protein, is modulated freeing up activins to stimulate FSH (Halvorson et al. 1994). Hence, we followed the mRNA encoding noggin, a BMP4 antagonist. No change for the level of this mRNA was observed between the studied stages. We can argue that antagonists other than noggin can be involved. However, the absence of variation in the mRNA encoding Id2 (Peng et al. 2004), one BMP target gene reflecting the bioactivity of BMP4 in ewe pituitary cells, does not fit with this idea. All together, the data suggest that pituitary BMP4 activity did not significantly vary over the estrous cycle.

Because the levels of pituitary mRNAs during the estrous cycle result from a complex interplay between local and peripheral molecules, we examined the specific action of major factors of FSH regulation on the expression of BMP4, BMP receptors, and Id 2 in cultured pituitary cells. Chronic treatment of pituitary cells with $\mathrm{GnRH}$ for $6 \mathrm{~h}$, mimicking a situation similar to the preovulatory surge, induced a decrease in the level of FSH $\beta$ mRNA. This is consistent with the reduction observed in vivo in pituitaries collected during the LH surge (Fafioffe et al. 2004). Moreover, this agrees with reports showing that chronic $\mathrm{GnRH}$ inhibits the activity of the oFSH $\beta$ promoter and the rat FSH $\beta$ expression in vivo and in vitro (Attardi et al. 1989, Lerrant et al. 1995, Shafiee-Kermani et al. 2007). This inhibition can result from a fall of FSH $\beta$ mRNA stability and/or a decrease of the transcription. In contrast, chronic GnRH did not modify the amount of mRNA for BMP4, BMP receptors, and Id2. Concerning the effect of the treatment with $\mathrm{E}_{2}$ for $48 \mathrm{~h}$, it inhibits the FSH $\beta$ mRNA and FSH release (data not shown) as expected (Miller et al. 1977, Baratta et al. 2001). However, $\mathrm{E}_{2}$ does not affect the expression of the mRNA for BMPR1A (ALK3) and BMPR2, but tends to increase that of BMPR1B (ALK6) mRNA. At this point, one could hypothesize that the effect of $\mathrm{E}_{2}$ on $\mathrm{FSH} \beta$ is partly mediated by BMPs through BMPR1B (ALK6). However, BMPR1B (ALK6) was not detected on gonadotrope cells (Faure et al. 2005, Young et al. 2008). Moreover, the observation that the BMPR1B (ALK6) mRNA expression did not change throughout the estrous cycle does not favor a role of this receptor in gonadotropin regulation. Rather, one might propose that the trend to increase BMPR1B (ALK6) mRNA stimulated by $E_{2}$ in vitro reflects the involvement of the BMP system in another pituitary function. For instance, Paez-Pereda et al. (2003) have shown that a BMP4/estrogen receptor regulatory mechanism exists in lactotroph cells and is critical for maintaining the balance between proliferation and differentiation. Also, previous studies demonstrated that BMP4 repressed proopiomelanocortin transcription in corticotroph cells (Nudi et al. 2005). Hence, the regulation of the pituitary BMP receptors in vivo may require factors other than those operating for the control of the estrous cycle. When cultured pituitary cells were treated with activin for $48 \mathrm{~h}$, the amount of mRNA for FSH $\beta$ increased as expected (Dupont et al. 2003). However, no change in the mRNAs for BMP4, BMP receptors, or Id2 was observed.

Another factor of the same TGF- $\beta$ family, activin, is considered a major intrapituitary regulator (Corrigan et al. 1991, Baratta et al. 2001, Padmanabhan \& McNeilly 2001). To compare the expression patterns of both BMP4 and activin, we analyzed the mRNA levels of activin subunits. Surprisingly, no study about the expression of pituitary activin across the ovine estrous cycle is available. Interestingly, our results showed that the level of the mRNA for activin $\beta \mathrm{B}$-subunit is higher before the secondary FSH surge compared to the other studied stages of the cycle. Also, the percentage of pituitary cells immunodetected with antibodies raised against $\beta \mathrm{B}$-subunit increased before the secondary $\mathrm{FSH}$ surge. In contrast, neither the levels of the mRNA for inhibin $\alpha$ - and activin $\beta A$-subunits nor the percentage of pituitary cells immunodetected with anti- $\alpha$ antibody varied significantly across the cycle. Together with the high levels of ActR2, ALK2, and ALK4 mRNA observed during the secondary surge of FSH (Fafioffe et al. 2004), these results 
reinforce the role of pituitary activin B as a major stimulus of FSH synthesis. Further evidence comes from exposure of ewe pituitary cells in culture to SB431542, an ALK4/5/7 inhibitor, showing inhibition of FSH release in a dosedependent manner. These data contrast with the lack of changes in the BMP4 system and underline the difference between pituitary BMP4 and activin.

In cultured ewe pituitary cells, treatment of cells with GnRH for $6 \mathrm{~h}$ did not modify the level of activin $\beta B$ mRNA. Similarly, in rat pituitary cells, chronic GnRH or rapid pulse frequency of $\mathrm{GnRH}$ did not affect activin $\beta \mathrm{B}$ mRNA levels in contrast to low pulse frequency (Demura et al. 1996, Dalkin et al. 1999). Treatment of pituitary cells with $E_{2}$ for $48 \mathrm{~h}$ increased the level of activin $\beta \mathrm{B}$ mRNA. This result is in contradiction with the data obtained by Baratta et al. (2001) who reported a decrease in activin $\beta B$ mRNA after $E_{2}$ treatment. Both studies used ewe pituitaries collected during the non-breeding season, and the reasons for this discrepancy are unclear. They may rely on differences in experimental conditions such as incubation medium or the duration of $\mathrm{E}_{2}$ treatment. The fact that $E_{2}$ increases activin $\beta B$ mRNA is surprising and does not fit with the negative effect of $E_{2}$ on FSH $\beta$ mRNA and FSH release. However, the increase, although reproducible, is weak and does not necessarily lead to a rise in activin protein. Moreover, we did not observe any difference in the amount of activin $\beta \mathrm{B}$ mRNA in vivo between luteal and late follicular phases when plasma concentrations of $E_{2}$ increase. However, the percentage of immunoreactive cells for $\beta B$ is decreased suggesting that $E_{2}$ can affect posttranscriptional events. Further study at the protein level is required. Furthermore, factors other than $\mathrm{E}_{2}$ can contribute to the control of activin $\beta \mathrm{B}$ expression. For instance, the rise in activin $\beta \mathrm{B}$ mRNA occurring before the secondary surge of FSH could be attributed to several factors such as the drop in circulating inhibin concomitantly to plasma $\mathrm{E}_{2}$ decrease and/ or to the low pulse frequency of GnRH.

Collectively, our data showed that changes in FSH $\beta$ expression were not associated with variations in the expression of BMP4, BMP receptors, Id2, or noggin. The constant levels may reflect a constitutive BMP signaling in the pituitary. Nonetheless, treatment of pituitary cells with noggin did not modify Id2 level, at least in vitro, suggesting the absence of endogenous signaling. Moreover, blocking the action of BMP4 potentially produced by pituitary cells with noggin does not affect the in vitro release of FSH. Hence, the results do not favor the hypothesis that local BMP4 would play a regulatory role on FSH secretion during the estrous cycle. However, we cannot exclude the possibility that other BMPs can affect FSH production. Previous studies demonstrated that pituitary exhibits at least BMP2 and BMP7 mRNA expression (Huang et al. 2001, Faure et al. 2005). Alternatively, one can argue that BMP receptors, and potentially BMP4, are widely expressed in the pituitary making it possible that changes in their expression in the gonadotrope cells are masked by stable expression in other cells. However, we previously reported that the vast majority of cells bearing the BMPR1A and BMPR2 was identified as gonadotropes (Faure et al. 2005). To confirm the lack of variations, it will be interesting to examine the expression of mRNAs for BMP4, BMP receptors, or Id2 at the gonadotrope cell level using in situ hybridization or immunohistochemistry. In addition, minor changes in mRNA expression evading detection may be sufficient to exert a paracrine/autocrine action. Nevertheless, the fact that treatment of pituitary cells with noggin, an antagonist of BMP4 and also BMP2 and BMP7, did not modify FSH release does not support this idea. This does not rule out a role for BMP4 on FSH synthesis and release in physiological conditions other than the estrous cycle such as pituitary development and/or in pituitary tumor. In contrast to BMP4, the amount of activin $\beta \mathrm{B}$ mRNA as well as the $\beta \mathrm{B}$-subunit in the pituitary was shown to increase before the secondary FSH surge strongly suggesting that activin is a major stimulus of FSH synthesis necessary for the secondary FSH surge. Moreover, blocking the action of activin potentially produced by pituitary cells with SB431542 in vitro inhibited FSH release demonstrating the importance of local activin. Further study is now needed to better identify the regulatory factors of activin synthesis related to FSH secretion.

In conclusion, this study expands current knowledge on local BMP4 and activin actions in the regulation of FSH synthesis and release. Our study presents a line of data that are not in favor of a paracrine/autocrine action of BMP4, in contrast to activin, on FSH production in adult pituitary during the estrous cycle. However, BMP4 or other BMPs may play a role as endocrine factors. Indeed, Herrera \& Inman (2009) showed the presence of BMP4, BMP6, and BMP9 in bovine serum. Further experiments are required to determine the presence or absence of BMPs in ovine serum and their physiological involvement in the regulation of FSH synthesis and release.

\section{Declaration of interest}

The authors declare that there is no conflict of interest that could be perceived as prejudicing the impartiality of the research reported.

\section{Funding}

This work was supported by Institut National de Recherches Agronomiques, the French 'Region Centre' and the Fonds d'aide à la Recherche Organon. $\mathrm{CS}$ was supported by a $\mathrm{PhD}$ fellowship from the Ministère de la Recherche et de la Technologie.

\section{Acknowledgements}

We thank Regeneron company (Tarrytown, NY, USA) for the gift of noggin. We are grateful to W Vale (La Jolla, CA, USA) for supplying antibodies raised against inhibin $\alpha-, \beta A$ - and $\beta B$-subunits. We thank Lionel Lardic for setting the estradiol RIA assay, François Lecompte for helping to collect blood samples, and Ida Boulay for technical assistance. We also thank the staff of INRA slaughterhouse and experimental farm for technical assistance. We acknowledge S Fabre for his advised comments. 


\section{References}

Allendorph GP, Vale WW \& Choe S 2006 Structure of the ternary signaling complex of a TGF- $\beta$ superfamily member. PNAS 103 7643-7648. (doi:10. 1073/pnas.0602558103)

Attardi B, Keeping HS, Winters SJ, Kotsuji F \& Troen P 1989 Effect of inhibin from primate Sertoli cells and GnRH on gonadotropin subunit mRNA in rat pituitary cell cultures. Molecular Endocrinology 3 1236-1242. (doi:10. 1210/mend-3-8-1236)

Baratta M, West LA, Turzillo AM \& Nett TM 2001 Activin modulates differential effects of estradiol on synthesis and secretion of folliclestimulating hormone in ovine pituitary cells. Biology of Reproduction 64 714-719. (doi:10.1095/biolreprod64.2.714)

Bilezikjian LM, Blount AL, Leal AM, Donaldson CJ, Fischer WH \& Vale WW 2004 Autocrine/paracrine regulation of pituitary function by activin, inhibin and follistatin. Molecular and Cellular Endocrinology 225 29-36. (doi:10.1016/j.mce.2004.02.010)

Carroll RS, Corrigan AZ, Gharib SD, Vale W \& Chin WW 1989 Inhibin, activin, and follistatin: regulation of follicle-stimulating hormone messenger ribonucleic acid levels. Molecular Endocrinology 3 1969-1976. (doi:10.1210/mend-3-12-1969)

Corrigan AZ, Bilezikjian LM, Carroll RS, Bald LN, Schmelzer CH, Fendly BM, Mason AJ, Chin WW, Schwall RH \& Vale W 1991 Evidence for an autocrine role of activin $\mathrm{B}$ within rat anterior pituitary cultures.

Endocrinology 128 1682-1684. (doi:10.1210/endo-128-3-1682)

Dalkin AC, Haisenleder DJ, Gilrain JT, Aylor K, Yasin M \& Marshall JC 1999 Gonadotropin-releasing hormone regulation of gonadotropin subunit gene expression in female rats: actions on follicle-stimulating hormone $\beta$ messenger ribonucleic acid (mRNA) involve differential expression of pituitary activin ( $\beta-\mathrm{B})$ and follistatin mRNAs. Endocrinology $140903-908$. (doi:10.1210/en.140.2.903)

Demura R, Suzuki T, Yajima R, Tajima S, Kubo O, Yoshimoto T \& Demura H 1996 Inhibin $\alpha, \beta_{\mathrm{A}}$ and $\beta_{\mathrm{B}}$ subunit messenger ribonucleic acid levels in cultured rat pituitary: studies by a quantitative RT-PCR. Endocrine Journal 43 403-410. (doi:10.1507/endocrj.43.403)

DePaolo LV, Bald LN \& Fendly BM 1992 Passive immunoneutralization with a monoclonal antibody reveals a role for endogenous activin-B in mediating FSH hypersecretion during estrus and following ovariectomy of hypophysectomized, pituitary-grafted rats. Endocrinology 130 1741-1743. (doi:10.1210/en.130.3.1741)

ten Dijke P, Yamashita H, Sampath TK, Reddi AH, Estevez M, Riddle DL, Ichijo H, Heldin CH \& Miyazono K 1994 Identification of type I receptors for osteogenic protein-1 and bone morphogenetic protein-4. Journal of Biological Chemistry 269 16985-16988.

Dupont J, McNeilly J, Vaiman A, Canepa S, Combarnous Y \& Taragnat C 2003 Activin signaling pathways in ovine pituitary and L $\beta$ T2 gonadotrope cells. Biology of Reproduction 68 1877-1887. (doi:10.1095/biolreprod.102. 012005)

Fafioffe A, Ethier JF, Fontaine J, JeanPierre E, Taragnat C \& Dupont J 2004 Activin and inhibin receptor gene expression in the ewe pituitary throughout the oestrous cycle. Journal of Endocrinology 182 55-68. (doi:10. 1677/joe.0.1820055)

Faure MO, Nicol L, Fabre S, Fontaine J, Mohoric N, McNeilly A \& Taragnat C 2005 BMP-4 inhibits follicle-stimulating hormone secretion in ewe pituitary. Journal of Endocrinology 186 109-121. (doi:10.1677/joe.1.05988)

Halvorson LM, Weiss J, Bauer-Dantoin AC \& Jameson JL 1994 Dynamic regulation of pituitary follistatin messenger ribonucleic acids during the rat estrous cycle. Endocrinology 134 1247-1253. (doi:10.1210/en.134.3.1247)

Herrera B \& Inman GJ 2009 A rapid and sensitive bioassay for the simultaneous measurement of multiple bone morphogenetic proteins. Identification and quantification of BMP4, BMP6 and BMP9 in bovine and human serum. BMC Cell Biology 10 20. (doi:10.1186/1471-2121-10-20)

Ho CC \& Bernard DJ 2009 Bone morphogenetic protein 2 signals via BMPR1A to regulate murine follicle-stimulating hormone $\beta$ subunit transcription. Biology of Reproduction 81 133-141. (doi:10.1095/biolreprod. 108.074211)
Huang HJ, Wu JC, Su P, Zhirnov O \& Miller WL 2001 A novel role for bone morphogenetic proteins in the synthesis of follicle-stimulating hormone. Endocrinology 142 2275-2283. (doi:10.1210/en.142.6.2275)

Kawabata M, Imamura T \& Miyazono K 1998 Signal transduction by bone morphogenetic proteins. Cytokine and Growth Factor Reviews 9 49-61. (doi:10.1016/S1359-6101(97)00036-1)

Kogawa K, Nakamura T, Sugino K, Takio K, Titani K \& Sugino H 1991 Activin-binding protein is present in pituitary. Endocrinology 128 1434-1440. (doi:10.1210/endo-128-3-1434)

de Kretser DM \& Robertson DM 1989 The isolation and physiology of inhibin and related proteins. Biology of Reproduction 40 33-47. (doi:10.1095/ biolreprod40.1.33)

Lee KB, Khivansara V, Santos MM, Lamba P, Yuen T, Sealfon SC \& Bernard DJ 2007 Bone morphogenetic protein 2 and activin A synergistically stimulate follicle-stimulating hormone $\beta$ subunit transcription. Journal of Molecular Endocrinology 38 315-330. (doi:10.1677/jme.1.02196)

Lerrant Y, Kottler ML, Bergametti F, Moumni M, Blumberg-Tick J \& Counis R 1995 Expression of gonadotropin-releasing hormone $(\mathrm{GnRH})$ receptor gene is altered by GnRH agonist desensitization in a manner similar to that of gonadotropin $\beta$-subunit genes in normal and castrated rat pituitary. Endocrinology 136 2803-2808. (doi:10.1210/en.136.7.2803)

Leung K, Kim KE, Maurer RA \& Landefeld TD 1988 Divergent changes in the concentrations of gonadotropin $\beta$-subunit messenger ribonucleic acid during the estrous cycle of sheep. Molecular Endocrinology 2 272-276. (doi:10.1210/mend-2-3-272)

Lewis KA, Gray PC, Blount AL, MacConell LA, Wiater E, Bilezikjian LM \& Vale W 2000 Betaglycan binds inhibin and can mediate functional antagonism of activin signalling. Nature 404 411-414. (doi:10.1038/ 35006129)

Ling N, Ying SY, Ueno N, Shimasaki S, Esch F, Hotta M \& Guillemin R 1986 A homodimer of the $\beta$-subunits of inhibin A stimulates the secretion of pituitary follicle stimulating hormone. Biochemical and Biophysical Research Communications 138 1129-1137. (doi:10.1016/S0006-291X(86)80400-4)

Macias-Silva M, Hoodless PA, Tang SJ, Buchwald M \& Wrana JL 1998 Specific activation of Smad1 signaling pathways by the BMP7 type I receptor, ALK2. Journal of Biological Chemistry 273 25628-25636. (doi:10. 1074/jbc.273.40.25628)

Miller WL, Knight MM, Grimek HJ \& Gorski J 1977 Estrogen regulation of follicle stimulating hormone in cell cultures of sheep pituitaries. Endocrinology 100 1306-1316. (doi:10.1210/endo-100-5-1306)

Miyazono K, Kusanagi K \& Inoue H 2001 Divergence and convergence of TGF- $\beta$ /BMP signaling. Journal of Cellular Physiology 187 265-276. (doi:10. 1002/jcp.1080)

Miyazono K, Kamiya Y \& Morikawa M 2010 Bone morphogenetic protein receptors and signal transduction. Journal of Biochemistry 147 35-51. (doi:10. 1093/jb/mvp148)

Monniaux D, Clemente N, Touze JL, Belville C, Rico C, Bontoux M, Picard JY \& Fabre S 2008 Intrafollicular steroids and anti-mullerian hormone during normal and cystic ovarian follicular development in the cow. Biology of Reproduction 79 387-396. (doi:10.1095/biolreprod.107.065847)

Morel G, Dubois P, Benassayag C, Nunez E, Radanyi C, Redeuilh G, Richard-Foy H \& Baulieu EE 1981 Ultrastructural evidence of oestradiol receptor by immunochemistry. Experimental Cell Research 132 249-257. (doi:10.1016/0014-4827(81)90100-2)

Nicol L, Faure MO, McNeilly JR, Fontaine J, Taragnat C \& McNeilly AS 2008 Bone morphogenetic protein-4 interacts with activin and GnRH to modulate gonadotrophin secretion in L $\beta \mathrm{T} 2$ gonadotrophs. Journal of Endocrinology 196 497-507. (doi:10.1677/JOE-07-0542)

Nudi M, Ouimette JF \& Drouin J 2005 Bone morphogenic protein (Smad)mediated repression of proopiomelanocortin transcription by interference with Pitx/Tpit activity. Molecular Endocrinology 19 1329-1342. (doi:10. 1210/me.2004-0425)

Otsuka F \& Shimasaki S 2002 A novel function of bone morphogenetic protein-15 in the pituitary: selective synthesis and secretion of FSH by gonadotropes. Endocrinology 143 4938-4941. (doi:10.1210/en.2002220929)

Padmanabhan V \& McNeilly AS 2001 Is there an FSH-releasing factor? Reproduction 121 21-30. (doi:10.1530/rep.0.1210021) 
Paez-Pereda M, Giacomini D, Refojo D, Nagashima AC, Hopfner U, Grubler Y, Chervin A, Goldberg V, Goya R, Hentges ST et al. 2003 Involvement of bone morphogenetic protein 4 (BMP-4) in pituitary prolactinoma pathogenesis through a Smad/estrogen receptor crosstalk. PNAS 100 1034-1039. (doi:10.1073/pnas.0237312100)

Peng Y, Kang Q, Luo Q, Jiang W, Si W, Liu BA, Luu HH, Park JK, Li X, Luo J et al. 2004 Inhibitor of DNA binding/differentiation helix-loop-helix proteins mediate bone morphogenetic protein-induced osteoblast differentiation of mesenchymal stem cells. Journal of Biological Chemistry 279 32941-32949. (doi:10.1074/jbc.M403344200)

Shafiee-Kermani F, Han SO \& Miller WL 2007 Chronic GnRH inhibits activin induction of the ovine FSH $\beta$ subunit: involvement of cAMP response element binding protein (CREB) and nitric oxide synthase type I (NOSI). Endocrinology 148 3346-3355. (doi:10.1210/en.2006-1740)

Taragnat C, Bernier A \& Fontaine J 1998 Gonadotrophin storage patterns in the ewe during the oestrous cycle or after long-term treatment with a GnRH agonist. Journal of Endocrinology 156 149-157. (doi:10.1677/joe.0.1560149)

Uccella S, La Rosa S, Genasetti A \& Capella C 2000 Localization of inhibin/activin subunits in normal pituitary and in pituitary adenomas. Pituitary 3 131-139. (doi:10.1023/A:1011431123208)

Vaughan JM, Rivier J, Corrigan AZ, McClintock R, Campen CA, Jolley D, Voglmayr JK, Bardin CW, Rivier C \& Vale W 1989 Detection and purification of inhibin using antisera generated against synthetic peptide fragments. Methods in Enzymology 168 588-617. (doi:10.1016/00766879(89)68044-5)
Wilson ME \& Handa RJ 1998 Activin subunit, follistatin, and activin receptor gene expression in the prepubertal female rat pituitary. Biology of Reproduction 59 278-283. (doi:10.1095/biolreprod 59.2.278)

Young JM, Juengel JL, Dodds KG, Laird M, Dearden PK, McNeilly AS, McNatty KP \& Wilson T 2008 The activin receptor-like kinase 6 Booroola mutation enhances suppressive effects of bone morphogenetic protein 2 (BMP2), BMP4, BMP6 and growth and differentiation factor-9 on FSH release from ovine primary pituitary cell cultures. Journal of Endocrinology 196 251-261. (doi:10.1677/JOE-07-0148)

Yu PB, Beppu H, Kawai N, Li E \& Bloch KD 2005 Bone morphogenetic protein (BMP) type II receptor deletion reveals BMP ligand-specific gain of signaling in pulmonary artery smooth muscle cells. Journal of Biological Chemistry 280 24443-24450. (doi:10.1074/jbc.M502825200)

Zwijsen A, Verschueren K \& Huylebroeck D 2003 New intracellular components of bone morphogenetic protein/Smad signaling cascades. FEBS Letters 546 133-139. (doi:10.1016/S0014-5793(03)00566-0)

Received in final form 12 July 2010

Accepted 20 July 2010

Made available online as an Accepted Preprint 30 July 2010 